\title{
ANALISIS LIKUIDITAS, LEVERAGE DAN KEBIJAKAN DIVIDEN BERDASARKAN SIKLUS HIDUP PERUSAHAAN PADA SAHAM LQ45
}

\author{
Novi Novita Sari ${ }^{1}$, Irdha Yusra ${ }^{2}$ \\ ${ }^{1,2)}$ Sekolah Tinggi Ilmu Ekonomi KBP \\ novinovitasari121@gmail.com \\ irdhayusra@gmail.com
}

\begin{abstract}
This study aims to find the influence of liquidity (X1) and leverage (X2) on the dividend policy $(Y)$ based on the life cycle of the company in the stock LQ45 period 20122016. This research is counducted on infomation obtaned through indonesi (BEI). This study usesmethode purposive sampling. The population in this study were companies in the index LQ45 which is listed active in indonesia (BEI) from 2012 until 2016 with a sample of 24 companies. The technique used is regression analisys. The result of liquidity research $(C R)$ does not have an effect on dividend policy (DPR) and leverage (DER) a have significant negative effect to dividend policy (DPR) at company LQ45.
\end{abstract}

Keyword: liquidity $(C R)$, leverage (DER), dividend policy (DPR)

\begin{abstract}
ABSTRAK
Penelitian ini bertujuan untuk mencari tahu pengaruh likuiditas (X1) dan leverage $(\mathrm{X} 2)$ terhadap kebijakan dividen $(\mathrm{Y})$ berdasarkan siklus hidup perusahaan pada saham LQ45 periode 2012-2016. Penelitian ini dilakukan berdasarkan informasi yang didapatkan melalui Bursa Efek Indonesia (BEI). Penelitian ini menggunakan metode observasi ,Prosedur penentuan sampel menggunakan metode purposive sampling. Populasi dalam penelitian ini adalah perusahaan-perusahaan pada indeks LQ45 yang tercatat aktif di Bursa Efek Indonesia dari tahun 2012 hingga 2016 dengan sampel 24 perusahaan. Teknik analisis yang digunakan adalah Analisis regresi panel.Hasil penelitian Likuiditas (CR) tidak berpengaruh terhadap kebijakan dividen (DPR) dan leverage (DER)berpengaruh negatif signifikan terhadap kebijakan dividen (DPR) pada perusahaan LQ45.
\end{abstract}

Kata Kunci: likuiditas (CR), leverage (DER), kebijakan dividen (DPR) 


\section{PENDAHULUAN}

Perkembangan perusahaan pada saham indeks LQ45 di Indonesia cukup pesat. Hal ini terlihat dari banyaknya perusahaan yang keluar dan masuk dalam lingkup indeks lq45 setiap periodenya. Dengan terjadinya hal ini, telah mencerminkan bahwa perusahaan yang terdaftatar pada indeks LQ45dibutuhkan oleh masyarakat.

Observasi awal telah dilakukan terhadap perusahaan LQ45 yang menjadi objek kajian ini. Perusahaan dituntut untuk mampu meningkatkan laba yang tinggi, agar calon investor tertarik dalam melakukan investasi. Investasi merupakan aktivitas yang dihadapkan pada berbagai risiko yang sulituntuk diprediksi oleh investor. Untuk mengurangi terjadinya risiko, investor membutuhkan berbagai macam informasi, mulai dari informasi tentang kinerja perusahaan, keadaan ekonomi, dan politik suatu negara (Susmita, 2013).

Investasi adalah kegiatan menanamkan sejumlah dana pada saat ini dengan tujuan untuk memperoleh return atau keuntungan di masa depan. Investasi dapat dilakukan pada aset nyata dan aset finansial. Pihak yang melakukan aktivitas investasi disebut dengan investor. Investor pada umumnya digolongkan menjadi dua, yaitu investor individual yang terdiri dari individu yang melakukan kegiatan investasi dan investor institusional yang terdiri dari lembaga-lembaga dan perusahaan-perusahaan yang melakukan kegiatan investasi(Sari, 2015). Dengan demikian segala aktivitas atau kegiatan yang dihadapkan kepada banyaknya risiko yang akan timbul dan menghasilkan keuntungan dimasa yang akan datang dinamakan dengan investasi.

Likuiditas bergantung pada arus kas perusahaan dan komponen aktiva lancar dan kewajiban lancarnya (Yusra 2016; Yusra, Hadya, and Fernandes 2017). Menurut Kristian (2014) likuiditas tidak hanya berkenaan dengan keadaan keseluruhan keuangan perusahaan, tetapi juga berkenaan dengan kemampuannya untuk mengubah aktiva lancar tertentu menjadi uang kas.Perusahaan harus mengubah aktiva lancar tertentu menjadi kas untuk membayar kewajiban lancarnya, misalnya perusahaan perlu menagih piutang atau menjual persediaannya sehingga perusahaan memperoleh kas.Likuiditas dipertimbangkan oleh manajemen dalam besarnya pembayaran dividen kas(Dewi, 2016).

Leverage merupakan kemampuan perusahaan untuk memenuhi kewajiban finansialnya baik jangka pendek maupun jangka panjang (Sari, 2015). Semakin tinggi rasio leverage menunjukan bahwa semakin besar kewajiban yang harus dipenuhi oleh perusahaan, sebaliknya semakin rendah rasio leverage menunjukan bahwa perusahaan mampu memenuhi kebutuhan pendanaan perusahaan dengan modal. 
Beberapa penelitian terdahulu telah melakukan penelitian secara empiris yang menemukan hasil yang berbeda-beda. (Mawarni, 2014) menemukan bahwa likuiditas berpengaruh negatif pada kebijakan dividen tunai, sedangkan(Susmita, 2013) menemukan bahwa likuiditas yang diproksikan dengan current ratio tidak berpengaruh pada kebijakan dividen tunai.Sari (2015) menyatakan bahwa hutang berpengaruh negatif terhadap kebijakan dividen dimana semakin tinggi tingkat hutang yang dimiliki perusahaan maka akan mengurangi pembagian dividen.

Mengingat banyaknya temuan-temuan empiris yang berbeda-beda mengenai pengaruh likuiditas dan leverage terhadap kebijakan dividen. Maka, penelitian ini menjadi menarik untuk dilakukan kajian secara mendalam, terutama untuk menjawab permasalahan tentang besarnya pengaruhlikuiditas dan leverage terhadap kebijakan dividen pada indeks LQ45. Dengan adanya permasalahan ini, penelitian ini dapat memberikan bukti secara empiris bahwa likuiditas tidak berpengaruh terhadap kebijakan dividen dan leverageberpengaruh negatif signifikan terhadap kebijakan dividen

\section{METODE PENELITIAN}

\section{Data dan Sampel}

Penelitian ini dilakukan pada perusahaan yang terdaftar dalam indeks LQ45, dasar pemilihan obyek ini adalah karena jumlah perusahaannya tetap setiap periode, juga disebabkan karena perusahaan yang terdaftar pada indeks LQ45 dapat mewakili unsur dasar yang digunakan dalam kehidupan sehari-hari. Perusahaan indeks LQ45 juga merupakan perusahaan yang

Sumber data dari penelitian ini berasal dari data sekunder yang bersumber dari www.idx.co.id. Jenis data yang diperoleh dari www.idx.co.id berupa data kuantitatif yang digunakan meliputi data yang diambil dari laporan keuangan perusahaan seperti laporan laba rugi, laporan arus kas, laporan neraca, laporan ekuitas dan catatan atas laporan keuangan akhir periode Desember 2012 sampai dengan 2016. Teknik analisis data yang digunakan adalah studi pustaka dan dokumentasi.

Populasi penelitian ini merupakan seluruh perusahaan yang terdaftar pada indeks lq45 selama periode 2012 sampai dengan periode 2016 yang berjumlah 78 perusahaan. Metode pengambilan sampel dalam penelitian ini dilakukan secara purposive sampling yaitu pengambilan sampel berdasarkan pertimbanganpertimbangan tertentu. Adapun kriteria yang digunakan dalam pengambilan sampel adalah sebagai berikut:

1. Perusahaan yang terdaftar di indeks lq45 selama periode 2012-2016

2. Perusahaan yang tidak menerbitkan laporan keuangan lengkap selama periode 2012-2016

Selain menggunakan pengambilan sampel secara purposive samplingpenelitian ini juga mengelompokkan sampel berdasarkan pada siklus hidup perusahan yang menggunakan percent sales growth. Sesuai dengan tabel berikut: 
Tabel 1.

Pengambilan Sampel Berdasarkan Siklus Hidup Perusahaan

\begin{tabular}{|l|l|l|}
\hline No & Tahapan & Nilai SGt \\
\hline 1. & Tahapan growth & Memiliki nilai SGt diatas 20\% \\
\hline 2. & Tahapan mature & Memiliki nilai SGt antara 8\% sampai 20\% \\
\hline 3. & Tahapan decline & Memiliki nilai SGt dibawah $8 \%$ \\
\hline
\end{tabular}

Sumber : Yulianti (2014)

Tabel 2

Daftar Perusahaan Sampel

\begin{tabular}{|c|l|c|c|}
\hline No & \multicolumn{1}{|c|}{ Perusahaan } & Kode & Kelompok perusahaan \\
\hline 1. & Adaro Energi tbk & ADRO & Decline \\
\hline 2. & AKR Corporindo tbk & AKRA & Decline \\
\hline 3. & Aneka Tambang & ANTM & Decline \\
\hline 4. & Astra Agro Lestari tbk & AALI & Decline \\
\hline 5. & Astra Internasional tbk & ASII & Decline \\
\hline 6. & Eagle Highplantation tbk & BWPT & Growth \\
\hline 7. & Elnusa tbk & ELSA & Decline \\
\hline 8. & Gajah Tunggal tbk & GJTL & Decline \\
\hline 9. & Gudang Garam tbk & GGRM & Mature \\
\hline 10. & Holcim indonnesia tbk & SMCB & Decline \\
\hline 11. & Indofood cbp sukses makmur tbk & ICBP & Mature \\
\hline 12. & Indofood sukses makmur tbk & INDF & Decline \\
\hline 13. & Indomobil sukses internasional tbk & IMAS & Decline \\
\hline 14. & Jasa marga tbk & JSMR & Mature \\
\hline 15. & Malindo feedmill tbk & MAIN & Mature \\
\hline 16. & Matahari departement store tbk & LPPF & Mature \\
\hline 17. & Mitra adi perkasa tbk & MAPI & Mature \\
\hline 18. & Multi polar tbk & MLPL & Decline \\
\hline 19. & Semen indonesia tbk & SMGR & Decline \\
\hline 20. & Telekomunikasi indonesia tbk & TLKM & Mature \\
\hline 21. & Tower Bersama infracstrukture tbk & TBIG & Mature \\
\hline 22. & Unilever indonesia tbk & UNVR & Mature \\
\hline 23. & United tractors tbk & UNTR & Decline \\
\hline 24. & Xl axiata tbk & EXCL & Decline \\
\hline & & & \\
\hline
\end{tabular}

\section{Definisi Operasional Variabel}

Variabel dalam penelitian terdiri dari dua macam, yaitu variabel bebas (independent variables) dan variabel terikat (dependent variables). Adapun yang menjadi variabel bebas dalam penelitian ini adalah Likuiditas sebagai $\mathrm{X}_{1}$ dan leverage sebagi $\mathrm{X}_{2}$. Sedangkan kebijakan dividen sebagai $\mathrm{Y}$ merupakan variabel terikat. 
Tabel 3

Definisi Operasional Variabel Penelitian

\begin{tabular}{|c|c|c|c|}
\hline No & Definisi & Pengukuran (Proxy) & Sumber \\
\hline 1. & $\begin{array}{l}\text { Kebijakan dividen merupakan } \\
\text { sebuah keputusan yang diambil } \\
\text { oleh perusahaan terkait dengan } \\
\text { dividen, apakah laba akan dibagi } \\
\text { kepada pemegang saham atau } \\
\text { investor dalam bentuk dividen } \\
\text { atau laba ditahan sebagai laba } \\
\text { pembiayaan investasi di masa } \\
\text { yang akan datang (Samrotun, } \\
\text { 2015). }\end{array}$ & $\mathrm{DPR}=\frac{\text { DividenperShare }}{\text { EarningperShare }}$ & $\begin{array}{l}\text { (Susmita, } \\
\text { 2013) }\end{array}$ \\
\hline 2. & $\begin{array}{l}\text { Likuiditas adalah kemampuan } \\
\text { perusahaan dalam mendanai } \\
\text { operasional perusahaan serta } \\
\text { untuk melunasi kewajiban jangka } \\
\text { pendeknya (Sari, 2015) }\end{array}$ & Current ratio $=\frac{\text { Curren Asset }}{\text { Curren Liability }} \times 100 \%$ & $\begin{array}{l}\text { (Amanah, } \\
\text { Atmanto } \\
\text { \& Azizah } \\
\text { 2014) }\end{array}$ \\
\hline 3. & $\begin{array}{l}\text { Leverage merupakan kemampuan } \\
\text { perusahaan untuk menggunakan } \\
\text { aktiva atau dana yang mempunyai } \\
\text { beban tetap untuk memperbesar } \\
\text { tingkat penghasilan bagi pemilik } \\
\text { perusahaan (Susmita, 2013). }\end{array}$ & DER $=\frac{\text { TotalDebt }}{\text { TotalShareholderEquity }}$ & $\begin{array}{l}\text { (Ramadh } \\
\text { ani, 2013) }\end{array}$ \\
\hline
\end{tabular}

\section{Metode Analisis Data}

Penelitian ini adalah penelitian pengujian hipotesis yang bertujuan untuk menguji pengaruh likuiditas dan leverage terhadap kebijakan dividen. Bentuk data yang digunakan dalam penelitian ini adalah data time series dan cross section. Secara substansial data panel mampu mengatasi masalah yang ditimbulkan akibat pengabaian variabel-variabel bebas yang relevan. Oleh karena itu untuk mengatasi masalah Secarasubtansial, data panel mampumengatasimasalah yang ditimbulkanakibatpengabaian variable-variabelbebas yang relevan (omitted variables). Olehkarenaitu, untukmengatasimasalahinterkorelasi yang padaakhirnyamengakibatkantidaktepatnyapenafsiranregresimakadigunakanmetode regresi data panel (Bond 2002). Data diambil dari 14 perusahaan sampel yang merupakan unit cross section dan data time series dari periode 2012 -2016.

Metodeanalisis yang digunakandalampenelitianiniyaituanalisisstatistikdeskriptifdananalisisregresi data 
panel denganbantuan Program EViews(Winarno 2011). Untuk mengetahui tingkat signifikansi dari masing-masing koefisien regresi variabel independen terhadap variabel dependen maka digunakan analisis regresi linear berganda yaitu dengan Ordinary Least Square. Regresi linear berganda merupakan teknik statistik yang digunakan untuk menguji pengaruh beberapa variabel bebas terhadap variabel terikat (Sekaran 2006). Persamaan regresi panel yang digunakan dalam penelitian ini adalah:

$$
\mathrm{DPR}_{\mathrm{it}}=\alpha+\beta_{1} \mathrm{CR}_{\mathrm{it}}+\beta_{2} \mathrm{DER}_{\mathrm{it}}+\mathrm{e}_{\mathrm{it}}
$$

Dimana $\mathrm{DPR}_{\mathrm{it}}$ merupakan likuiditas Perusahaan pada waktu $\mathrm{t} ; \alpha$ merupakan konstanta (intercept); $\beta_{1}, \beta_{2}$ merupakan Koefisien Regresi; $\mathrm{CR}_{\mathrm{it}}$ merupakan likuiditas Perusahaan pada waktu $\mathrm{t}, \mathrm{CR}_{\mathrm{it}}$ merupakan leverage Perusahaan pada waktu t; dan e merupakan Faktor penganggu (Disturbance Error)

PendekatanCommon Effect, Fixed Effect, danRandom Effect jugadilakukandalamanalisisregresi data panel (Drukker 2003; Bond 2002). Penentuan model mana yang paling tepatdigunakan di antaraketiga model tersebutterdiridaribeberapatahapan, yaitu:

1. Uji Chow, dilakukanuntukmenentukanapakah model Common Effect lebihbaikdigunakandaripadaFixed Effect.

2. UjiHausman, dilakukanuntukmenentukanapakah model Fixed Effect lebihbaikdigunakandaripadaRandom Effect.

Model regresi yang dilakukan adalah berdasarkan pada siklus hidup perusahaan tahapan growth, mature, decline pada Random Effect Model

\section{HASIL DAN PEMBAHASAN}

\section{Analisis Statistik Deskriptif}

Uji statistik deskriptif bertujuan untuk memberikan gambaran umum obyek penelitian. Perhitungan statistik deskriptif dalam penelitian ini meliputi nilai minimum, maksimum, rata-rata, maupun standar deviasi masing-masing variabel. Distribusi masing-masing variabel berdasarkan siklus hidup perusahaan pada tahapan growth, mature, dan decline adalah sebagai berikut:

\section{Tabel 4}

\section{Deskriptif Statistik DPR, CR dan DER Pada Kelompok Perusahaan yang tergolong Growth}

\begin{tabular}{|c|c|c|c|c|c|}
\hline Variabel & $\mathbf{N}$ & Minimum & Maximum & Mean & Standar Deviasi \\
\hline DPR & 5 & 0.0 & 18.54 & 6.38 & 8.92 \\
\hline CR & 5 & 44.62 & 73.82 & 61.25 & 12.49 \\
\hline DER & 5 & 1.36 & 1.95 & 1.69 & 0.22 \\
\hline
\end{tabular}


Pada tabel 4.2 diatas dapat dijelaskan bahwa nilai terendah untuk kebijakan dividen yang diukur dengan dividend payout ratio(DPR) pada perusahan yang tergolong tahapan growth yaitu pada perusahaan Eagle Highplantation tbk pada tahun 2014 sampai dengan 2016 adalah sebesar 0.0 sedangkan nilai tertingginya adalah 18.54 pada perusahaan Eagle Highplantation tbk pada tahun 2012 Secara rata-rata dividen yang dibagikan oleh perusahaan pada tahapan growthadalah sebesar 6.83. Standar deviasi kebijakan dividen yang diukur dengan dividend payout ratio (DPR) sebesar 8.92 dengan jumlah observasi sebanyak 5 .

Nilai terendah untuk likuiditas yang diukur dengan current ratio(CR) adalah sebesar 44.62 pada perusahaan Eagle Highplantation tbk tahun 2013 sedangkan nilai tertingginya adalah 73.82 pada perusahaan Eagle Highplantation tbk tahun 2016 . Secara rata-rata kemampuan perusahaan membayarkan hutang jangka pendeknya dengan memanfaatkan aset jangka pendek adalah sebesar 61.25. Standar deviasi likuiditas yang diukur dengan current ratio (CR) adalah 12.49 dengan jumlah observasi sebanyak 5 .

Nilai terendah untuk leverageyang diukur dengan debt to equity ratio(DER) adalah sebesar 1.36 pada perusahaan Eagle Highplantation tbk tahun 2014 sedangkan nilai tertingginya adalah sebesar 1.95 pada perusahaan Eagle Highplantation tbk tahun 2016 . Secara rata-rata kemampuan perusahaan untuk menggunakan aktiva atau dana yang mempunyai beban tetap untuk memperbesar tingkat penghasilan bagi pemilik perusahaan(DER) adalah sebesar 1.69 yang. Standar deviasi leverage (DER) adalah 0.22 dengan jumlah observasi sebanyak 5 .

Tabel 5

Deskriptif Statistik DPR, CR, DER pada kelompok perusahaan yang tergolong Mature

\begin{tabular}{|c|c|c|c|c|c|}
\hline Variabel & $\mathbf{N}$ & Minimum & Maximum & Mean & $\begin{array}{c}\text { Standar } \\
\text { Deviasi }\end{array}$ \\
\hline DPR & 45 & 0.00 & 99.96 & 28.08 & 31.02 \\
\hline CR & 45 & 34.55 & 276.25 & 123.10 & 57.65 \\
\hline DER & 45 & -4.76 & 18.19 & 2.24 & 3.75 \\
\hline
\end{tabular}

Pada tabel 5 dapat dijelaskan bahwa nilai terendah untuk kebijakan dividen yang diukur dengan dividend payout ratio (DPR) adalah sebesar 0.00 pada perusahaan Gudang Garam tbk tahun 2016, Indofood Cbp Sukses Makmur tbk tahun 2012 dan 2016,Indika Energy tbk thun 2013 sampai tahun 2016, Jasa Marga tbk tahun 2014 dan 2016,Matahari Departement Store tbk tahun 2012, 2014 dan 2016, Malindo Feedmil tbk tahun 2014 sampai 2016, Mitra Adi Perkasa tbk tahun 2014 sampai 2016, Tower Bersama Infracstrukture tbk tahun 2012, 2014 dan 2015, Telekomunikasi indonesia tbk tahun 2014. Nilai tertingginya 99.96 terdapat pada perusahaan Unilever tbk tahun 2012. Serta rata-rata dividen yang dibagikan perusahaan adalah sebesar 20.08dengan standar deviasi 31.02 dan jumlah observasi sebanyak 45 .

Nilai terendah untuk Likuiditas yang diukur dengan current ratio(CR) adalah sebesar 34.55 yang terdapat pada perusahaan Tower Bersama 
Infracstrukture tbk tahun 2014 dan nilai tertingginya sebesar 276.25 terdapat padaperusahaan Indofood Cbp Sukses Makmur tbk tahun 2012. Secara rata-rata kemampuan perusahaan membayarkan hutang jangka pendeknya dengan memanfaatkan aset jangka pendek (CR) adalah adalah sebesar 123.10, dengan standar deviasi 57.65 dengan jumlah observasi sebanyak 45 .

Nilai terendah untuk leverage yang diukur dengan debt to equity ratio (DER) adalah sebesar -4.76 yang terdapat pada perusahaanMatahari Departement Store tbk pada tahun 2013 dan nilai tertingginya sebesar 18.19 terdapat pada perusahaan Matahari Departement Store tbkpada tahun 2014. Secara rata-rata kemampuan perusahaan untuk menggunakan aktiva atau dana yang mempunyai beban tetap untuk memperbesar tingkat penghasilan bagi pemilik perusahaan(DER) adalah sebesar 2.24 dengan standar deviasi 3.75 dan jumlah observasi sebanyak 45 .

Tabel 6

Deskriptif Statistik DPR, CR, DER pada kelompok perusahaan yang tergolong Decline

\begin{tabular}{|c|c|c|c|c|c|}
\hline Variabel & $\mathbf{N}$ & Minimum & Maximum & Mean & $\begin{array}{c}\text { Standar } \\
\text { Deviasi }\end{array}$ \\
\hline DPR & 70 & -60.47 & 70.00 & 26.33 & 25.79 \\
\hline CR & 70 & 41.86 & 259.32 & 146.95 & 53.51 \\
\hline DER & 70 & 0.33 & 3.56 & 1.14 & 0.71 \\
\hline
\end{tabular}

Pada tabel 6 dapat dijelaskan bahwa nilai terendah kebijakan dividen yang diukur dengan dividend payout ratio(DPR) terdapat pada perusahaan Indomobil Sukses International tbk pada tahun 2015 sebesar -60.47 dan nilai tertinggi sebesar 70.00 terdapat pada perusahaan Elnusa tbk pada tahun 2014. Serta ratarata dividen yang dibagikan perusahaan (DPR) adalah sebesar 26.33 serta standar deviasinya sebesar 25.79 dengan jumlah observasi sebanyak 70 .

Nilai terendah likuiditas yang diukur dengan current ratio(CR) terdapat sebesar 41.86 pada perusahaan XL Axiata pada tahun 2012 dan nilai tertinggi sebesar 259.32 CR terdapat pada perusahaan Aneka Tambang tbk pada tahun 2015. Secara rata-rata kemampuan perusahaan membayarkan hutang jangka pendeknya dengan memanfaatkan aset jangka pendek (CR) adalah146.95 serta standar deviasinya sebesar 53.51 dengan jumlah observasi sebanyak 70 .

Nilai terendah leverage yang diukur dengan debt to equity ratio (DER) terdapat sebesar 0.33 pada perusahaan Astra Agro Lestari tbk tahun 2012 dan nilai tertinggi sebesar 3.56 terdapat pada perusahaan XL Axiata tbk pada tahun 2014. Secara rata-rata kemampuan perusahaan untuk menggunakan aktiva atau dana yang mempunyai beban tetap untuk memperbesar tingkat penghasilan bagi pemilik perusahaan (DER) adalah sebesar 1.14 serta standar deviasinya sebesar 0.71 dengan jumlah observasi sebanyak 70 .

\section{Pemilihan Regresi Data Panel}

Tahapan analisis yang digunakan untuk menentuka model model estimasi terbaik dalam data panel yaitu dengan melakukan estimasi model Common Effect 
(CEM), Fixed Effect (FEM), danRandom Effect (REM). Persamaanregresi yang digunakanuntukmengestimasi model tersebutadalahsebagaiberikut:

$$
\mathrm{DPR}_{\mathrm{it}}=\alpha+\beta_{1} \mathrm{CR}_{\mathrm{it}}+\beta_{2} \mathrm{DER}_{\mathrm{it}}+\mathrm{e}_{\mathrm{it}}
$$

Hasil statistik yang diperolehdalampengestimasian model CEM, FEM, dan REM adalahsebagaiberikut:

Tabel 7

Hasil Estimasi Common Effect Model, Fixed Effect Model dan Random Effect Model

\begin{tabular}{|l|c|c|c|c|c|c|}
\hline & \multicolumn{2}{|c|}{ Common Effect Model } & \multicolumn{2}{c|}{ Fixed Effect Model } & \multicolumn{2}{c|}{$\begin{array}{c}\text { Random Effect } \\
\text { Model }\end{array}$} \\
\hline Variabel & t-Stat & Prob & t-Stat & Prob & t-Stat & Prob \\
\hline CR & 0.061930 & 0.9570 & -0.129391 & 0.8973 & 0.071401 & 0.9432 \\
\hline DER & -1.721723 & 0.0878 & -0.688399 & 0.4929 & -1.127975 & 0.2616 \\
\hline
\end{tabular}

Tabel di atasmenunjukkanbahwanilai $\mathrm{t}$ statistik, probabilitas dan $\mathrm{R}$ Squareduntukmasing-masing model sebagaidasarpemilihan model terbaikdalamregresi data panel.Hasilestimasimenjelaskanbahwamasing-masing model memilikinilaisignifikansi yang berbeda-beda.Olehsebabitu, untukmenemukan model mana yang terbaikmakadilakukananalisislebihlanjutdenganmenggunakanUji Chow danHausman Test.

Tabel 8

Uji Chow

\begin{tabular}{|l|r|r|r|}
\hline \multicolumn{2}{|l|}{ Redundant Fixed Effects Tests } & & \\
\hline Equation: Untitled & & \\
\hline Test cross-section fixed effects & & \\
\hline \hline Effects Test & Statistic & d.f. & Prob. \\
\hline \hline Cross-section F & 3.773794 & $(23,94)$ & 0.0000 \\
\hline Cross-section Chi-square & 78.489781 & 23 & 0.0000 \\
\hline
\end{tabular}

Uji chow bertujuanuntukmenentukan model yang lebihbaikdigunakanantara model Common Effect danFixed Effect.Berdasarkantabel di atasdiperolehnilaiprobpadaCross-section Chi-square lebih kecil dari alpha $(\alpha)$ $(0.0000<0.05)$, maka $\mathrm{H}_{0}$ ditolak. Artinya model Fixed Effectlebihbaikdigunakandari model Common Effect. 
Tabel 9

Uji Hausman

\begin{tabular}{|c|c|c|c|}
\hline \multicolumn{3}{|c|}{ Correlated Random Effects - Hausman Test } & \\
\hline \multirow{2}{*}{\multicolumn{3}{|c|}{ Equation: Untitled }} & \\
\hline & & & \\
\hline Test Summary & $\begin{array}{l}\text { Chi-Sq. } \\
\text { Statistic }\end{array}$ & Chi-Sq. d.f. & Prob. \\
\hline Cross-section random & 1.314987 & 2 & 0.5181 \\
\hline
\end{tabular}

UjiHausmanbertujuanuntukmenentukan model yang lebihbaikantara model Fixed Effect dan model Random Effect. Tabel 8 menunjukkanbahwanilaiprobpadaCross-section random lebih kecil dari alpha $(\alpha)$ $(0.51>0.05)$, sehingga $\mathrm{H}_{0}$ diterima. Dengan demikian, dapat disimpulkan bahwa model yang cocok digunakan dalam regresi data panel adalah Fixed Effect Model (FEM).

\section{Analisis Regresi data panel}

Penelitian ini dilakukan untuk melihat pengaruh variabel independen terhadap variabel dependen. Analisis regresi data panel digunakan untuk melihat apakah hipotesis yang telah dibuat akan diterima atau ditolak. Tingkat signifikansi yang digunakan adalah 5\%. Model statistik yang diestimasi merupakan model yang terbaikdanterbebasdaripenyimpanganasumsiklasik. Untuk mengetahui hasil pengujian hipotesis dari analisis regresi data panel pada tahapan growth, mature, dan decline dapat dilihat pada Tabel berikut ini:

Tabel 10

HasilUji Regresi Data PanelPada Tahapan Growth

\begin{tabular}{|c|c|c|c|c|}
\hline \multicolumn{3}{|c|}{ Dependent Variable: DPR } & & \\
\hline \multicolumn{3}{|c|}{ Method: Least Squares } & & \\
\hline \multicolumn{3}{|c|}{ Date: 02/06/18 Time: 12:07 } & & \\
\hline \multicolumn{3}{|c|}{ Sample: 20122016} & & \\
\hline \multicolumn{3}{|c|}{ Included observations: 5} & & \\
\hline Variable & Coefficient & Std. Error & t-Statistic & Prob. \\
\hline $\mathrm{C}$ & -35.15977 & 19.61941 & -1.792091 & 0.2150 \\
\hline $\mathrm{CR}$ & -0.279173 & 0.179106 & -1.558704 & 0.2594 \\
\hline DER & 34.70020 & 9.953589 & 3.486199 & 0.0733 \\
\hline
\end{tabular}

Dari hasil estimasi data panel dapat dituliskan persamaan sebagai berikut :

$\mathrm{DPR}=-35.15977-2.79173 \mathrm{CR}+34.70020 \mathrm{DER}$ 
Berdasarkan pada model persamaan diatas dapat diinterprestasikan, yaitu :

1. Nilai konstanta sebesar -35.15977 bermakna bahwa jika diasumsikan nilai CR dan DER bernilai 0 (nol), maka nilai DPR sama besarnya dengan -35.15977.

2. Koefisien regresi likuiditas (CR) sebesar -2.79173 bermakna bahwa setiap peningkatan $\mathrm{CR}$ sebesar 1 satuan, maka akan menyebabkan penurunan DPR sebesar -2.79173

3. Koefisien regresi leverage (DER) sebesar 34.70020 bermakna bahwa setiap peningkatan DER sebesar 1 satuan maka akan menyebabkan peningkatan DPR sebesar 34.70020.

Tabel 11

Hasil Uji Regresi Data Panel Pada Tahapan Mature

\begin{tabular}{|c|c|c|c|c|}
\hline \multicolumn{3}{|c|}{ Dependent Variable: DPR } & & \\
\hline \multicolumn{5}{|c|}{ Method: Panel EGLS (Cross-section random effects) } \\
\hline \multicolumn{3}{|c|}{ Date: 02/14/18 Time: 06:19 } & & \\
\hline \multicolumn{5}{|c|}{ Sample: 20122016} \\
\hline \multicolumn{5}{|c|}{ Periods included: 5} \\
\hline \multicolumn{5}{|c|}{ Cross-sections included: 9} \\
\hline \multicolumn{5}{|c|}{ Total panel (balanced) observations: 45} \\
\hline \multicolumn{5}{|c|}{ Swamy and Arora estimator of component variances } \\
\hline Variable & Coefficient & Std. Error & t-Statistic & Prob. \\
\hline CR & -0.091287 & 0.119711 & -0.762565 & 0.4500 \\
\hline DER & -0.798197 & 1.140725 & -0.699728 & 0.4880 \\
\hline $\mathrm{C}$ & 41.11471 & 17.05435 & 2.410804 & 0.0204 \\
\hline
\end{tabular}

Dari hasil estimasi data panel dapat dituliskan persamaan sebagai berikut :

$\mathrm{DPR}=41.11417-0.091287 \mathrm{CR}-0.798197 \mathrm{DER}$

Berdasarkan pada model persamaan diatas dapat diinterprestasikan, yaitu:

1. Nilai konstanta sebesar 41.11417 bermakna bahwa jika diasumsikan nilai likuiditas yang diukur dengan current ratio(CR) danleverage yang diukur dengan debt to equity ratio (DER) bernilai 0 (nol), maka nilai kebijakan dividen yang diukur dengan dividend payout ratio(DPR) sama besarnya dengan 41.11417

2. Koefisien regresi likuiditas yang diukur dengan current ratio (CR) sebesar -0.091287 bermakna bahwa setiap peningkatan CR sebesar 1 satuan, maka akan menyebabkan penurunan DPR sebesar -0.091287.

3. Koefisien regresi leverage yang diukur dengan debt to equity ratio (DER) sebesar -0.798197 bermakna bahwa setiap peningkatan DER sebesar 1 satuan maka akan menyebabkan penurunan DPR sebesar 0.7981974 . 
Tabel 12

Hasil Uji Regresi Data Panel Pada Tahapan Decline

\begin{tabular}{|c|c|c|c|c|}
\hline \multicolumn{3}{|c|}{ Dependent Variable: DPR } & & \\
\hline \multicolumn{5}{|c|}{ Method: Panel EGLS (Cross-section random effects) } \\
\hline \multicolumn{3}{|c|}{ Date: 02/14/18 Time: 06:22 } & & \\
\hline \multicolumn{5}{|c|}{ Sample: 20122016} \\
\hline \multicolumn{5}{|c|}{ Periods included: 5} \\
\hline \multicolumn{5}{|c|}{ Cross-sections included: 14} \\
\hline \multirow{2}{*}{\multicolumn{5}{|c|}{ Total panel (balanced) observations: 70}} \\
\hline Swamy and Arora estimator of component variances & & & & \\
\hline Variable & Coefficient & Std. Error & t-Statistic & Prob. \\
\hline $\mathrm{CR}$ & -0.004804 & 0.073085 & -0.065730 & 0.9478 \\
\hline DER & -14.61884 & 5.295955 & -2.760378 & 0.0074 \\
\hline $\mathrm{C}$ & 43.77919 & 14.42207 & 3.035569 & 0.0034 \\
\hline
\end{tabular}

Dari hasil estimasi data panel dapat dituliskan persamaan sebagai berikut :

$\mathrm{DPR}=43.77919-0.004804 \mathrm{CR}-14.61884 \mathrm{DER}$

Berdasarkan pada model persamaan diatas dapat diinterprestasikan, yaitu sebagai berikut :

1. Nilai konstanta sebesar 43.77919 bermakna bahwa jika diasumsikan nilai yang diukur dengan current ratio (CR) danleverage yang diukur dengan debt to equity ratio(DER) bernilai 0 (nol), maka nilai kebijakan dividen yang diukur dengan dividend payout ratio (DPR) sama besarnya dengan 43.77919.

2. Koefisien regresi likuiditas yang diukur dengan current ratio(CR) sebesar -0.004804 bermakna bahwa setiap peningkatan CR sebesar 1 satuan, maka akan menyebabkan penurunan DPR sebesar -0.004804CR

3. Koefisien regresi leverage yang diukur dengan debt to equity ratio (DER) sebesar -14.61884 bermakna bahwa setiap penurunan DER sebesar 1 satuan maka akan menyebabkan peningkatan DPR sebesar -14.61884.

\section{Hasil pengujian hipotesis}

Tabel 13

Hasil Pengujian Hipotesis Pada Masing-Masing Kelompok Perusahaan Menggunakan Random Effect Model

\begin{tabular}{|c|c|c|c|c|c|c|}
\hline & \multicolumn{2}{|c|}{ Growth } & \multicolumn{2}{c|}{ Mature } & \multicolumn{2}{c|}{ Decline } \\
\hline Variabel & t-Stat & Prob & t-Stat & Prob & t-Stat & Prob \\
\hline CR & -1.558704 & 0.2594 & -0.762565 & 0.45 & -0.06573 & 0.9478 \\
\hline DER & 3.486199 & 0.0733 & -0.699728 & 0.488 & -2.76038 & 0.0074 \\
\hline
\end{tabular}


Pada tabel di atas dapat dijelaskan t statistik menunjukkan seberapa jauh pengaruh variabel independen secara individual dalam menerangkan variabel dependen. Tabel 4.14 menjelaskan bahwa pada tahapan growth perbandingan antara nilai $t$ statistik dengan nilai t tabel dari CR adalah sebesar $(-1.56<1.98)$ dan nilai probabilitas yang dibandingkan dengan nilai alpha adalah sebesar 0.2594 $<0.05$. Hal ini membuktikan bahwa CR tidak berpengaruh terhadap DPR. Sedangkan perbandingan antara nilai $\mathrm{t}$ statistik dengan nilai $\mathrm{t}$ tabel dari DER adalah sebesar $3.48>1.98$ dan nilai probabilitas yang dibandingkan dengan nilai alpha adalah sebesar $0.0733>0.05$. Hal ini membuktikan bahwa DER tidakberpengaruh terhadap DPR.

Pada tahapan mature perbandingan antara nilai $\mathrm{t}$ statistik dengan nilai $\mathrm{t}$ tabel dari $\mathrm{CR}$ adalah sebesar $(-0.76<1.98)$ dan nilai probabilitas yang dibandingkan dengan nilai alpha adalah sebesar $(0.45>0.05)$. Hal ini membuktikan bahwa CR tidak memiliki pengaruh terhadap DPR. Sedangkan perbandingan antara nilai $t$ statistik dengan nilai t tabel dari DER adalah sebesar ($0.69<1.98)$ dengan perbandingan nilai probabilitas dengan alpha sebesar $(0.48>$ 0.05). Hal ini membuktikan bahwa DER tidak berpengaruh terhadap kebijkan dividen.

Pada tahapan decline perbandingan antara nilai $\mathrm{t}$ statistik dengan nilai $\mathrm{t}$ tabel dari $\mathrm{CR}$ adalah sebesar $(-0.06<1.98)$ dan nilai probabilitas yang dibandingkan dengan nilai alpha adalah sebesar $(0.94>0.05)$. Hal ini membuktikan bahwa CR tidak berpengaruh terhadap kebijakan dividen. Sedangkan perbandingan nilai $\mathrm{t}$ statistik dengan nilai t tabel dari DER adalah sebesar $(-2.76<1.98)$ dan nilai probabilitas yang dibandingkan dengan nilai alpha sebesar $(0.007<0.05)$. Hal ini dapat membuktikan bahwa DER berpengaruh negatif dan signifikan terhadap DPR.

\section{Pembahasan}

Hasil analisis data untuk hipotesis pertama yang menyatakan bahwa Likuiditas perusahaan tidak berpengaruh terhadap kebijakan dividen. Hal ini terjadi karena pada tahapan growth jumlah observasi hanya sedikit dan tidak mencapai jumlah minimal observasi yang telah ditetapkan. Hasil penelitian ini sejalan dengan penelitian Arilaha (2009) yang menyatakan bahwa likuiditas tidak berpengaruh terhadap kebijakan dividen dan Susmita (2013) juga menyatakan bahwa likuiditas yang diukur dengan current ratio tidak memiliki pengaruh terhadap kebijakan dividen.

Hasil analisis data untuk hipotesi kedua yang menyatakan bahwa terdapat pengaruh negatif signifikan antara leverage terhadap kebijakan dividen. Pengaruh ini dapat dilihat pada tahapan decline. Hasil penelitian membuktikan secara parsial leverage berpengaruh negatif signifikan terhadap kebijakan dividen. Apabila hutang suatu perusahaan meningkat maka kemampuannya untuk membayar dividen akan semakin kecil dan apabila hutang suatu perusahaan menurun maka kemampuannya untuk membayar dividen akan semakin besar. Signifikannya pengaruh leverage terhadap kebijakan dividen karena besarnya leverage dapat membuat perusahaan menurunkan kemampuannya membayarkan dividen. 


\section{Kesimpulan}

Berdasarkan hasil pengujian yang dan pembahasan yang telah dilakukan sebelumnya, maka dapat diperoleh kesimpulan bahwa, Likuiditas yang diukur dengan current ratio (CR) tidak berpengaruh signifikan terhadap kebijakan dividen yang diukur dengan dividend payout ratio (DPR) sesuai dengan pendapat Arilaha (2009) yang menyatakan bahwa likuiditas tidak berpengaruh terhadap kebijakan dividen dan leverage yang diukur dengan debt to equity ratio (DER) memiliki pengaruh negatif dan signifikan terhadap kebijkan dividen yang diukur dengan dividend payout ratio (DPR) sejalan dengan pendapat Paramitha (2015) yang menyatakan bahwa debt to equity ratio memiliki pengaruh negatif terhadap dividend payout ratio.

Ada beberapa keterbatasan yang ditemukan dalam penelitian ini, diantaranya adalah Penelitian ini menggunakan dua variabel bebas yaitu likuiditas yang diukur dengan current ratio (CR) dan leverageyang diukur dengan debt to equityratio (DER) yang hasil dari pengujian CR tidak berpengaruh terhadap kebijakan dividen dan DER berpengaruh negatif dan tidak signifikan disarankan untuk penelitian selanjutnya menambahkan variabel bebas agar hasil penelitian lebih baik. Misalnya : menambah variabel ROE dan DOL dan Penelitian ini hanya menggunakan sebanyak 24 perusahaan indeks LQ45 saja sehingga menghasilkan penelitian yang belum signifikan, disarankan pada penelitian selanjutnya menggunakan semua perusahaan yang terdaftar di BEI. Keterbatasan lainnya adalah penelitian hanya menggunakan 5 periode observasi, sehingga belum menemukan hasil yang sesuai dengan ekspektasi peneliti. Untuk penelitian berikutnya disarankan untuk menambah atau memperpanjang periode pengamatan. Misalnya: menggunakan 10 tahun terakhir. Hal ini diharapkan agar hasil penelitian lebih baik.

\section{UCAPAN TERIMAKASIH}

Peneliti mengucapkan terima kasih kepada pihak-pihak yang telah memberikan dukungan dan dorongan dalam melakukan penelitian ini. Penghargaan dan ucapan terima kasih kepada Bursa Efek Indonesia yang telah menyediakan akses kedalam laporan keuangan tahunan (annual report) perusahaan yang terdaftar di BEI. Sehingga memudahkan peneliti untuk mengumpulkan data sesuai dengan data yang peneliti butuhkan. 


\section{DAFTAR PUSTAKA}

Amanah, Raghilia, Dwi Atmanto, and Devi Farah Azizah. 2014. "Pengaruh Rasio Likuiditas Dan Rasio Profitabilitas Terhadap Harga Saham." Jurnal Administrasi Bisnis.

Arilaha, Muhammad Asril. 2009. "Leverage Terhadap Kebijakan Dividen" 13 (1):78-87.

Bond, Stephen R. 2002. "Dynamic Panel Data Models: A Guide to Micro Data Methods and Practice." Portuguese Economic Journal 1 (141-162).

Dewi, Dian Masita. 2016. "Pengaruh Likuiditas, Leverage, Ukuran Perusahaan Terhadap Kebijakan Dividen Tunai Dengan Profitabilitas Sebagai Variabel Intervening." Jurnal Bisnis Dan Ekonomi.

Drukker, David M. 2003. "Testing for Serial Correlation in Linear Panel-Data Models." The Stata Journal 3 (2):168-77. https://doi.org/The Stata Journal.

Kristian, N dan Khuzaini. 2014. "Pengaruh Likuiditas Dan Profitabilitas Terhadap Struktur Modal Dan Rasio Aktivitas Sebagai Intervening." Jurnal Ilmu \& Riset Manajemen.

Mawarni, Luh Fajarini Indah dan Ni Made Dwi Ratnadi. 2014. "Penagruh Kesempatan Investasi, Leverage, Dan Likuiditas Pada Kebijakan Dividen Perusahaan Manufaktur Yang Terdaftar Di BEI.” Jurnal Akuntansi.

Paramitha, Sista. 2015. "Free Cash Flow, Leverage, Besaran Dan Siklus Hidup Perusahaan." Jurnal Riset Ekonomi Dan Manajemen.

Ramadhani, Rani. 2013. "Pengaruh Return on Assets Dan Debt to Equity Ratio Terhadap Harga Saham Pada Institusi Finansial Di BEI.” Jurnal the Winners.

Samrotun, Yuli Chomsatu. 2015. "Kebijakan Dividen Pada Perusahaan Industri Barang Konsumsi Yang Terdaftar Di Bursa Efek Indonesia ( BEI ).” Jurnal Paradigma 13 (01):92-103.

Sari, Komang Ayu Novita dan Luh Komang Sudjarni. 2015. "Pengaruh Likuiditas, Leverage, Pertumbuhan Perusahaan, Dan Profitabilitas Terhadap Kebijakan Dididen Pada Perusahaan Manufaktur Di BEI." Journal Management.

Sekaran, Uma. 2006. Research Methods For Business. Empat. Jakarta: Salemba Empat.

Susmita, I Putu Yoga. 2013. "Analisis Likuiditas Dan Laverage Terhadap Kebijakan Dividen.” Jurnal Akuntansi.

Winarno, Wing Wahyu. 2011. Aplikasi Ekonometrika Dan Statistika Dengan EViews. 3rd ed. Yogyakarta: UPP STIM YKPN. 
Yulianti, Nur Wachidah. 2014. "Siklus Hidup Perusahaan Dan Konservatisme Akuntansi." Jurnal Bisnis Dan Manajemen.

Yusra, Irdha. 2016. "Kemampuan Rasio Likuiditas Dan Solvabilitas Dalam Memprediksi Laba Perusahaan: Studi Empiris Pada Perusahaan Telekomunikasi Yang Terdaftar Di Bursa Efek Indonesia." Jurnal Benefita 1 (1):33-42. https://doi.org/http://dx.doi.org/10.22216/jbe.v1i1.878.

Yusra, Irdha, Rizka Hadya, and Joni Fernandes. 2017. "Likuiditas , Financial Leverage, Dan Prediktabilitas Beta: Pendekatan Fowler and Rorke Sebagai Metode Koreksi Beta.” Jurnal Benefita 2 (1):81-91. 